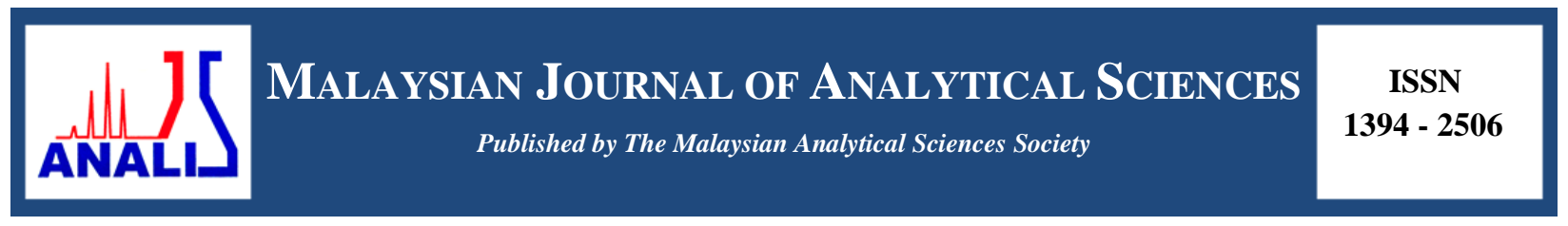

\title{
CHARACTERISATION OF CATFISH (Clarias batrachus) OIL: $\beta$-CYCLODEXTRIN INCLUSION COMPLEX
}

\section{(Pencirian Kompleks Rangkuman Minyak Ikan Keli (Clarias batrachus): $\beta$-siklodekstrin)}

\author{
Zaibunnisa Abdul Haiyee ${ }^{1}$, Nor Izzatul Adyani Yahya ${ }^{1}$, Norizzah Abd Rashid ${ }^{1}$, Dzulkifly Mat Hashim ${ }^{2}$ \\ ${ }^{I}$ Food Technology Programme, Faculty of Applied Sciences, \\ Universiti Teknologi MARA, 40450 Shah Alam, Selangor, Malaysia \\ ${ }^{2}$ Halal Products Research Institute, \\ Universiti Putra Malaysia, Putra Infoport, 43400 UPM Serdang, Selangor, Malaysia
}

*Corresponding author: nisha@salam.uitm.edu.my

Received: 24 February 2015; Accepted: 27 October 2015

\begin{abstract}
Catfish is a cheap source of essential omega-3 fatty acids especially eicosapentaenoic acid (EPA) and docosahexaenoic acid (DHA). Catfish oil was extracted and clean-up using pressurised liquid extraction (PLE) from the viscera of catfish (Clarias batrachus). However, the characteristics of catfish oils are sticky, strong fishy odour and can easily be oxidised with short shelflife. In this study, catfish oil was converted into powder by formation of inclusion complex with $\beta$-cyclodextrin. Inclusion complex was prepared by using co-precipitation and kneading methods and compared with physical mixture. The inclusion complex formed were characterised by using field emission scanning electron microscopy (FESEM), differential scanning calorimeter (DSC) and fourier transform infrared spectroscopy (FTIR). FESEM images revealed that inclusion complex using co-precipitation and kneading methods has smaller in crystal sizes and appeared as different morphology compared to physical mixture. DSC proved that co-precipitation method was able to form new solid phase due to shifting of melting point to-higher temperature $\left(145.22{ }^{\circ} \mathrm{C}\right)$. FTIR supported the result by proving strengthening of carbonyl group $(\mathrm{C}=\mathrm{O})$. Therefore, coprecipitation method was able to successfully produce inclusion complex of catfish oil, $\beta$-cyclodextrin.
\end{abstract}

Keywords: catfish oil, $\beta$-cyclodextrin, co-precipitation, kneading, physical mixture

\section{Abstrak}

Ikan keli merupakan sumber murah yang mengandungi asid lemak omega-3 terutama asid eikosapentaenoik (EPA) dan asid dokosaheksaenoik (DHA). Minyak ikan keli telah diekstrak dan disulingkan dengan menggunakan pengekstrakan cecair tekanan tinggi (PLE) daripada visera ikan keli (Clarias batrachus). Walau bagaimanapun, ciri - ciri minyak ikan keli adalah melekit, bau hanyir yang kuat, mudah teroksida dengan mempunyai jangka hayat yang terhad. Dalam kajian ini, minyak ikan keli telah ditukarkan menjadi serbuk melalui pembentukan kompleks rangkuman dengan $\beta$-siklodekstrin (BCD). Kompleks rangkuman telah dihasilkan dengan menggunakan teknik ko-pemendakan dan penggulian serta dibandingkan dengan campuran fizikal. Kompleks rangkuman telah dicirikan dengan menggunakan mikroskop elektron imbasan medan (FESEM), kalorimeter imbasan kebezaan (DSC) dan spektrofotometer infra merah transformasi fourier (FTIR). Hasil kajian daripada imej FESEM menunjukkan bahawa pembentukan kompleks rangkuman menggunakan teknik ko-pemendakan dan penggulian mempunyai saiz kristal yang kecil dan muncul sebagai morfologi yang berbeza dibandingkan dengan campuran fizikal. DSC membuktikan ko-pemendakan mampu menghasilkan fasa baru kerana takat pencairan berubah dari yang asal ke suhu yang lebih tinggi $\left(145.22^{\circ} \mathrm{C}\right)$. FTIR mendokong keputusan melalui bukti penegangan kumpulan karbonil dan $\mathrm{C}=\mathrm{O}$ telah digunakan untuk rangkuman. Oleh itu, kaedah ko-pemendakan membuktikan kaedah yang paling sesuai untuk merangkum minyak ikan keli menggunakan $\beta$-siklodekstrin.

Kata kunci: minyak ikan keli, $\beta$-siklodekstrin, ko-pemendakan, penggulian, campuran fizikal 


\section{Introduction}

The walking catfish, Clarias batrachus represents a cheap priced food fish and a great deal of attention is now being paid for popularization of its mass culture [1,2]. Recently, catfish have high demand in marketplace since catfish contribute a lot of nutritional value to human and other industry. Every year a considerable amount of total catch is discarded as processing leftovers and that include trimmings, fins, frames, head, skin and viscera. Some of the byproducts are utilized, but the main bulk is dumped into waste, creating both disposal and pollution problems. Annual discard is estimated to be about $25 \%$ of the total production of capture [3]. Most of the oil in catfish is found in the viscera, which contain approximately $33 \%$ fats or other lipids which could be converted into edible oil [4]. The oil extracted from fish is rich in polyunsaturated fatty acids (PUFAs) especially those of the omega-3 family, mainly eicosapentaenoic acid (EPA; C20:5n-3) and docosahexaenoic acid (DHA; C22:6n-3). The importance of PUFAs in human health and nutrition is well recognized in preventing cardiovascular diseases, Alzheimer's disease and psoriasis $[4,5]$.

One of the major drawbacks of oils containing a high amount of omega-3 PUFA such as fish oils is their susceptibility to oxidation which involves the formation of toxic products such as peroxides or volatile compounds which contribute to undesirable off flavours [5]. Encapsulation is a technology of packing solid, liquid or gaseous materials in miniature sealed capsules for release at controlled rates using desired released triggers [6]. Some researchers have reported that the encapsulation of fish oil significantly retards lipid oxidation. It can also mask the objectionable odours caused by volatile oxidation products and enhance the odor of fish oil enriched products [5]. Cyclodextrin has been extensively used in areas such as pharmaceutical, cosmetic and food industries because it is inexpensive and non-toxic. Using the molecular inclusion method, cyclodextrin can solubilise and stabilise active compounds on the molecular scale. Cyclodextrin can form solid phases by self-assembly. This process depends on the solubility, temperature, $\mathrm{pH}$, molecular weight and chemical nature of guest materials [6].

In this study, microencapsulation of catfish oil with $\beta$-cyclodextrin (BCD) will be used to overcome this problem. Two methods can be used to produce inclusion complex namely co-precipitation, and kneading [7]. Physical mixture product will usually act as a control [8]. Characterisation of the encapsulated products was performed to confirm formation of inclusion complex. The inclusion complex formed were characterised using Fourier Transform Infrared Spectroscopy (FTIR), Field Emission Scanning Electron Microscopy (FESEM) and Differential Scanning Calorimeter (DSC). The resultant water soluble fish oil in powdered form has many applications such as food, pharmaceutical and medical fields. In addition, results from this study will be useful for future research that involves other fish oils that contain high PUFAs especially DHA and EPA.

\section{Materials}

\section{Materials and Methods}

The $\beta$-cyclodextrin (BCD) (purity: $99.5 \%$ ) was purchased from the Sigma Chemical Company (St. Louis, MO, USA). All solvents were of analytical grade. Ethanol (ACS Reagent, Ph Eur Merck, Germany) were of pharmaceutical grade and the water was deionised using a Milli-QUV device (Millipore, Molsheim, France).

\section{Sample preparation}

Fresh catfish viscera were obtained from local supplier in Kajang, Selangor. The samples were kept in plastics bags and transported in an insulated container to the laboratory. Upon arrival at the laboratory, the sample was washed under running tap water. The samples were ground with a commercial blender for 10 minutes and kept at $-20{ }^{\circ} \mathrm{C}$ in the freezer until further use. Prior to PLE extraction method; samples were dried using freeze dryer at $-50{ }^{\circ} \mathrm{C}$ for 5 days. The dried samples were freezed at $-20{ }^{\circ} \mathrm{C}$ until needed for extraction.

\section{Pressurised liquid extraction}

Extractions were done using ASE 200 accelerated solvent extractor (Dionex Ltd. Camberley, Surrey, UK). Catfish oil was extracted using n-hexane with predetermined optimised conditions (Design Expert 6.0.4, Stat Ease Software): temperature of $96{ }^{\circ} \mathrm{C}$, pressure of $15,140 \mathrm{kPa}$ and static time of $17 \mathrm{~min}$. The extract was evaporated to dryness using a rotary evaporator. 


\section{Inclusion complex}

The inclusion complex of catfish oil: BCD (1:8) was prepared using the kneading and co-precipitation methods. The kneading method and physical mixture as control were as reported by Zhang et al. [7]. The method for coprecipitation was referring to method by Waleczek et al. [8].

\section{Characterisation of the inclusion complex: Differential scanning calorimetry (DSC)}

DSC analyses were carried out using Perkin Elmer DSC1 STAR System. An amount $5 \mathrm{mg}$ sample was placed in aluminium pans and heated at $10^{\circ} \mathrm{C} / \mathrm{min}$ in the temperature range of $0{ }^{\circ} \mathrm{C}$ to $300{ }^{\circ} \mathrm{C}$. The measurements were carried out under dry nitrogen at a flow rate of $50 \mathrm{~mL} / \mathrm{min}[8]$.

\section{Fourier transform infrared spectroscopy (FTIR)}

The FTIR spectra of catfish oil, BCD, their physical mixture and the inclusion complex were measured between 4000 and $400 \mathrm{~cm}^{-1}$ using a Perkin Elmer Model GX FTIR spectrophotometer (Waltham, MA, USA), with 16 scans at a resolution of $1 \mathrm{~cm}^{-1}$. The $\mathrm{KBr}$ disk method was used for the solid samples [8].

\section{Field emission scanning electron microscopy (FESEM)}

The surface morphology of the dried samples was examined using a scanning electron microscope, Model Supra 40VP (GEMINI). Prior to analysis, the samples were attached to SEM aluminium stubs via 2 -sided adhesive tape. The attached powder was then sputter coated for $50 \mathrm{~s}$ at a beam current of $0 \mathrm{~mA}$ to obtain a $15 \mathrm{~nm}$ layer of goldpalladium alloy and was then examined using a scanning electron microscope operating at $5 \mathrm{Kv}$ [8].

\section{Statistical analysis}

A one-way analysis of variance (ANOVA) and Duncan's Multiple Range test $(p<0.05)$ were used to establish the significance of differences in analysis data. The analyses were performed using SPSS 16.0 for Windows software.

\section{Differential scanning calorimetry (DSC)}

\section{Results and Discussion}

The thermal behaviour of catfish oil with $\beta$-cyclodextrin (BCD) inclusion complex was studied using Differential Scanning Calorimetry (DSC). The thermograms of pure BCD and catfish oil-BCD physical mixture, kneading, coprecipitation and pure catfish oil, were represented in Figure 1.

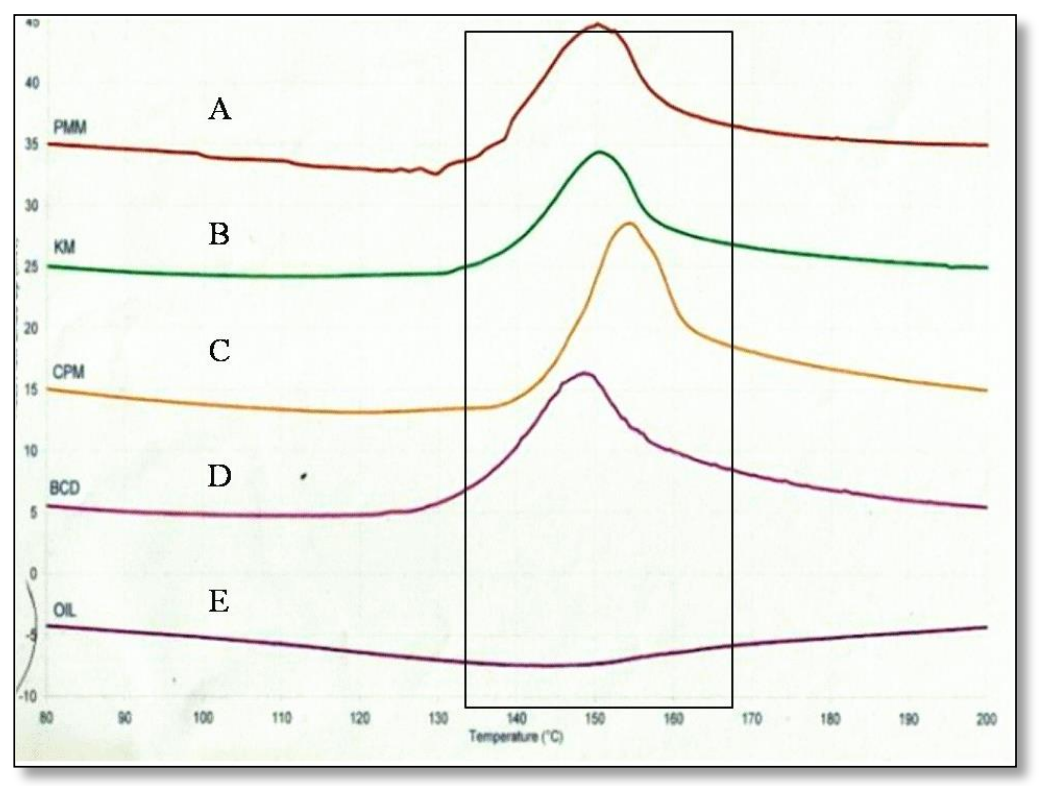

Figure 1. DSC thermograms of physical mixture (PMM) (A), kneading (KM) (B), co-precipitation (CPM) (C), $\beta$-cyclodextrin (BCD) (D) and catfish oil (Oil) (E) 
Table 1. Data obtained from DSC thermograms.

\begin{tabular}{lrrr}
\hline & $\mathbf{T}_{\text {Onset }}\left({ }^{\circ} \mathbf{C}\right)$ & $\mathbf{T}_{\text {Peak }}\left({ }^{\circ} \mathbf{C}\right)$ & $\mathbf{T}_{\text {Endset }}\left({ }^{\circ} \mathbf{C}\right)$ \\
\hline Catfish oil (Oil) & $92.31 \pm 0.05$ & $143.60 \pm 0.12$ & $175.39 \pm 0.05$ \\
$\beta$-cyclodextrin (BCD) & $139.10 \pm 0.11$ & $148.47 \pm 0.05$ & $158.50 \pm 0.03$ \\
Co-precipitation method (CM) & $145.22 \pm 0.08$ & $154.18 \pm 0.05$ & $163.81 \pm 0.15$ \\
Kneading method (KM) & $139.07 \pm 0.05$ & $150.31 \pm 0.01$ & $159.15 \pm 0.02$ \\
Physical mixture method (PMM) & $138.01 \pm 0.04$ & $149.99 \pm 0.07$ & $159.36 \pm 0.01$ \\
\hline
\end{tabular}

\section{Fourier transform infrared spectroscopy (FTIR)}

The complexation between catfish oil and BCD was further investigated by using FTIR and the spectra obtained were shown in Figure 2. FTIR is a useful technique used to confirm the formation of an inclusion complex [10].

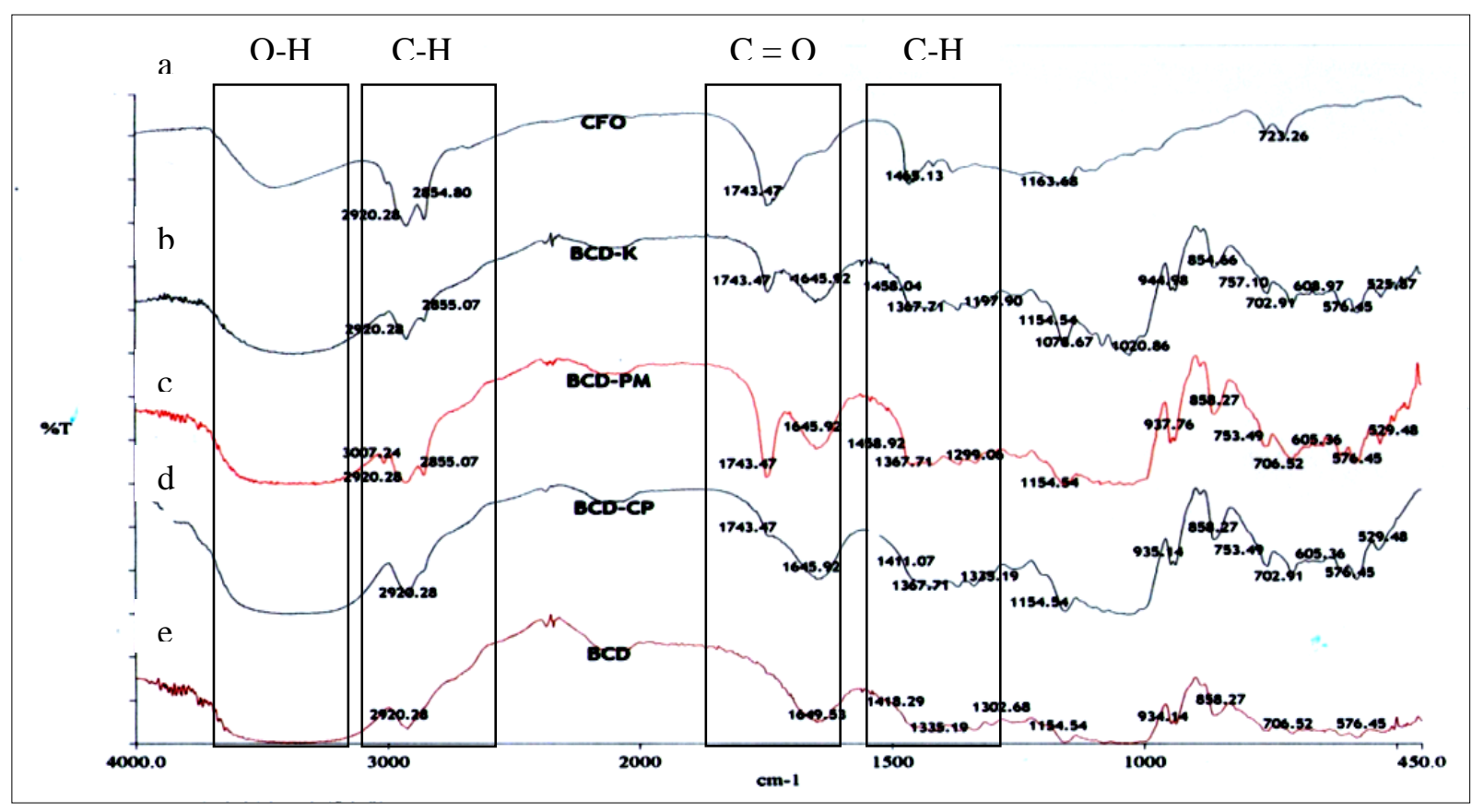

Figure 2. FTIR spectrum of catfish oil (CFO) (a), kneading (BCD-K) (b), physical mixture (BCD-PM) (c), $\beta$ - coprecipitation (BCD-CP) (d), and $\beta$-cyclodextrin (BCD) (e)

Overall, catfish oil bands were masked from cyclodextrin as the main component of complexes formation. Generally, the stretching region of hydroxyl group, $-\mathrm{OH}$ was shown at the band range of $3600-3200 \mathrm{~cm}^{-1}$. The band at $3400 \mathrm{~cm}^{-1}$ indicates the presence of hydroxyl group in the catfish oil. The presence of water in BCD resulted in the presence of broad peak of $\mathrm{O}-\mathrm{H}$ which masks the presence of $-\mathrm{OH}$ in catfish oil.

A few bands of alkanes $(\mathrm{C}-\mathrm{H})$ are shown at $2930-2800 \mathrm{~cm}^{-1}$. The C-H peak appeared at $2920 \mathrm{~cm}^{-1}$ and $2855 \mathrm{~cm}^{-1}$ can be observed in the catfish oil and $2920 \mathrm{~cm}^{-1}$ for BCD. Inclusion complex band formed by coprecipitation method were shifted to higher wavenumber indicate that the conjugation in catfish oil was reduced in the presence of $\mathrm{BCD}$. This result indicates $\mathrm{C}-\mathrm{H}$ been used for inclusion complex. The band for carbonyl group 
$(\mathrm{C}=\mathrm{O})$ peaks appeared at the band range of $1650-1620 \mathrm{~cm}^{-1}$. The FTIR studies indicated that a cyclodextrin complex was formed with guest molecules possessing carbonyl group [12].

The intensity of this band appeared reduced for co-precipitation, kneading and physical mixture methods. This indicated that carbonyl group been used for complexation. A few bands of alkanes $(\mathrm{C}-\mathrm{H})$ were shown at $1300-$ $1512 \mathrm{~cm}^{-1}$. The wavenumber for catfish oil was noticed at $1465 \mathrm{~cm}^{-1}$ and $1418 \mathrm{~cm}^{-1}$ for BCD. The intensity of this band appeared reduced for co-precipitation and kneading. This indicated that $\mathrm{C}-\mathrm{H}$ group also been used for complexation. A stronger interaction of inclusion complex might be seen in co-precipitation process due to almost similar peak to the pure BCD compared to kneading and physical mixture.

\section{Field emission scanning electron microscopy (FESEM)}

FESEM provides qualitative information on study of pure substance and complexes formation by different methods of preparation. In recent study, FESEM observation was done in collaboration with DSC and FTIR to verify the occurrence of BCD-catfish oil complexes formation. This helps to assess existence of any products during the process [8]. The FESEM images of pure BCD, catfish oil; co-precipitation, kneading and physical mixture products at 2500 times magnification are shown in Figure 3.

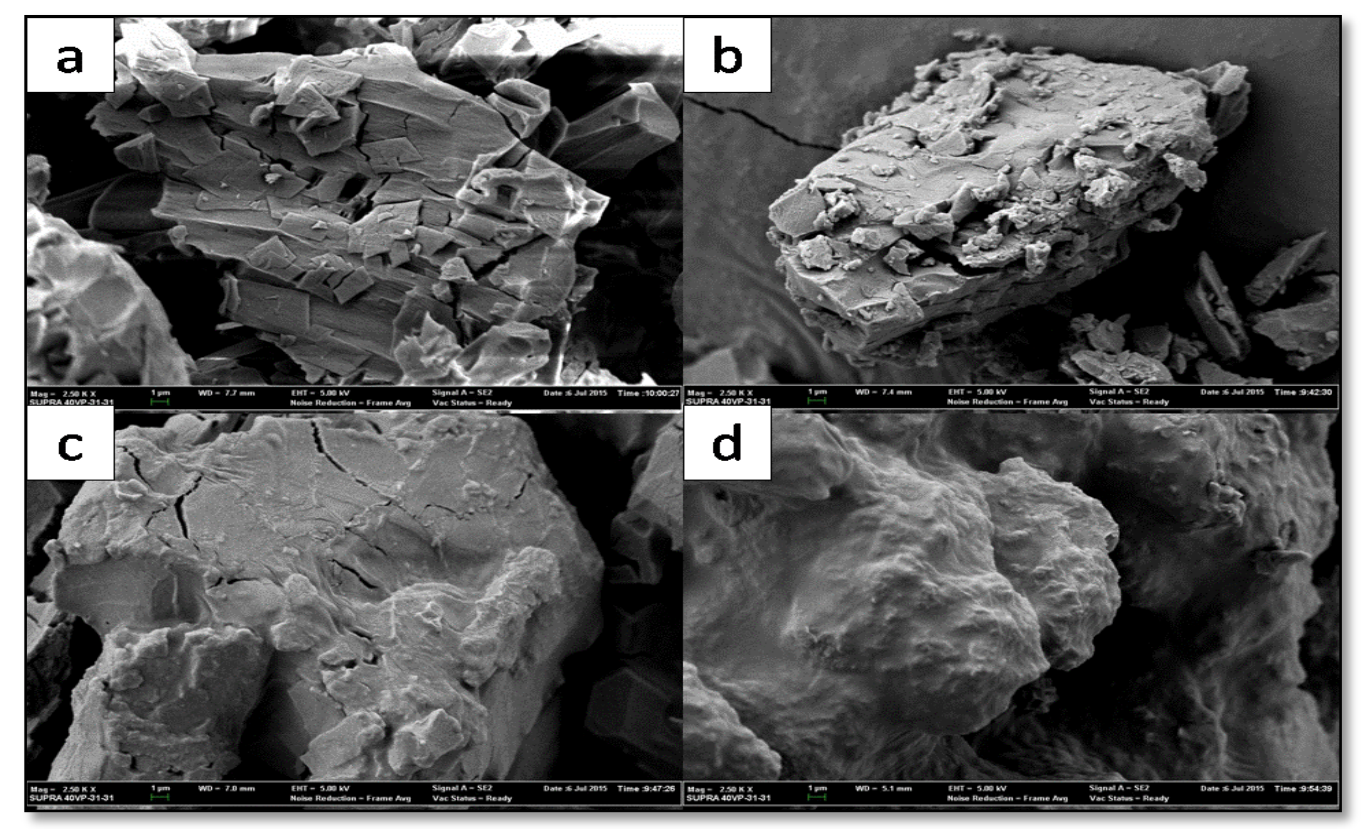

Figure 3. FESEM illustration of (a) $\beta$-cyclodextrin (BCD), (b) co-precipitation, (c) kneading and (d) physical mixture at magnification $\mathrm{x} 2500$

Particle size for $\mathrm{BCD}$ as shown in Figure 3 (a) was appeared bigger than other samples. It due to the commercial pure $\mathrm{BCD}$ was well structured, plated and parallelogram shape. The shape of kneaded complexes as shown in Figure 3 (c) appear quite different from the co-precipitation complexes (Figure 3 (b)). The products appears as irregular and clumping to each other. The drastic change of the particles shape and aspects in the co-precipitation sample were indicative of the presence of a new solid phase, leading us to suggest the existence of a single phase. Previous study by Reddy et al. [11] reported similar findings for a cyclodextrin: celecoxib system. Physical mixture of BCD with catfish oil (Figure 3 (d)) forms sticky and clumps to each other. This appearance as big oily agglomerates was clearly seen under SEM observation. Furthermore, the oiliness of structure can be seen on the surface of the complexes. Thus, an inclusion complex may not formed for BCD using this physical mixture method. This finding supported by Zaibunissa et al. [12] which stated that the new solid phase of oleoresin and cyclodextrins 
formed using the co-precipitation method appeared as a crystal structure which was completely different from the original morphology of its pure compounds.

\section{Conclusion}

The interaction between $\mathrm{C}-\mathrm{H}$ and $\mathrm{BCD}$ resulted in the formation of an inclusion complex. The formation of the inclusion complex was investigated and confirmed using DSC, FTIR and FESEM analysis. The results obtained from this study will be very useful for producing odourless catfish oil powder from cheap source. Kneading and physical mixture were able to form loose interaction inclusion complex. However, co-precipitation was the chosen method for the potential of future study.

\section{Acknowledgement}

The authors would like to acknowledge financial support of Universiti Teknologi MARA and Ministry of Higher Education for the Exploratory Research Grant Scheme (ERGS) (ERGS/1/2011/STG/UITM/01/10). Laboratory facilities for the utilisation of pressurised liquid extraction (PLE), fourier transform infrared spectroscopy (FTIR), differential scanning calorimetry (DSC) and field emission scanning electron microscope (FESEM) in Forensic Chemistry Laboratory, Universiti Teknologi MARA are kindly appreciated.

\section{References}

1. Nayak, S., Solanki, H. U. and Dwivedi, R. M. (2003). Utilization of IRS P4 ocean colour data for potential fishing zone- a cost benefit analysis. Indian Journal of Marine Sciences, 32 (3): 244 - 248.

2. Malaysia Department of Fisheries (2004). Perangkaan Perikanan Tahunan 2004. Access from http://www.dof.gov.my/index.php/pages/view/111

3. Tacon, A. G. J. and Metian, M. (2008). Global overview on the use of fish meal and fish oil in industrially compounded aquafeeds: trends and future prospects. Aquaculture, 285: 146-158.

4. Simopoulus, A. P., Leaf, A. and Salem, N. (1999). Essentiality of and recommended dietary intakes for omega6 and omega-3 fatty acids. Annals Nutrition and Metabolism, 43: $127-131$.

5. Haraldsson, G .G., Kristinsson, B., Sigurdardottir, R., Gudmundsson, G.G. and Breivik, H. (1997). The preparation of concentrates of eicosapentaenoic acid and docosahexaenoic acid by lipase-catalyzed transesterification of fish oil with ethanol. Journal of the American Oil Chemist's Society, 74: 1419 - 1424.

6. Choi, M. J., Ruktanonchai, U., Min, S. G., Chun, J. Y. and Soottitantawat, A. (2010). Physical characteristics of fish oil encapsulated by $\beta$-cyclodextrin using an aggregation method or polycaprolactone using an emulsiondiffusion method. Food Chemistry, 119 (4): $1694-1703$.

7. Zhang, A., Liu, W., Wang L. and Wen, Y. (2005). Characterization of Inclusion Complexation between Fenoxaprop-p-ethyl and Cyclodextrin. Journal of Agricultural and Food Chemistry, 53 (18): 7193 - 7197.

8. Waleczek, K. J., Marques, C., Hempel, B. and Schmidt, P. C. (2003). Phase solubility studies of pure (2)-abisabolol and camomile essential oil with b-cyclodextrin. European Journal of Pharmaceutics and Biopharmaceutics, 55: $247-251$.

9. Zaibunnisa, A. H., Siti Rashima, R. and Nur Ain, A.H. (2011). Stabilization of curcumin with $\gamma$-cyclodextrin: phase solubility study and its characterisation. $2^{\text {nd }}$ International Conference on Biotechnology and Food Science IPCBEE, 7: 9 - 13.

10. William III, R. O., Mahaguna, V. and Sriwongjany, M. (1998). Characterization of an inclusion complex of cholesterol with hydroxyproopyl- $\beta$-cyclodextrins. European Journal of Pharmaceutics and Biopharmaceutics, 46: $355-360$.

11. Reddy, M. N., Rehana, T., Ramakrishna, S., Chowdary, K. P. R. and Diwan, P. V. (2004). $\beta$-cyclodextrin complexes of celecoxib: molecular modelling, characterization, and dissolution studies. AAPS Pharmaceutical Sciences, 6(1): $1-9$.

12. Zaibunnisa, A. H., Norashikin, S., Mamot, S., Rosli, M. I., Wan A, W. M. and Osman, H. (2009). Characterization of cyclodextrin complexes with turmeric oleoresin. Food Chemistry. 114: 459-465. 